\title{
LONG-TERM CHANGES IN WATER AREAS AND WETLANDS IN AN INTENSIVELY FARMED LANDSCAPE: A CASE STUDY FROM THE CZECH REPUBLIC
}

\author{
Markéta Šantrůčková, Katarína Demková, Martin Weber ${ }^{1}$, \\ Zdeněk Lipský², Jiří Dostálek ${ }^{1}$
}

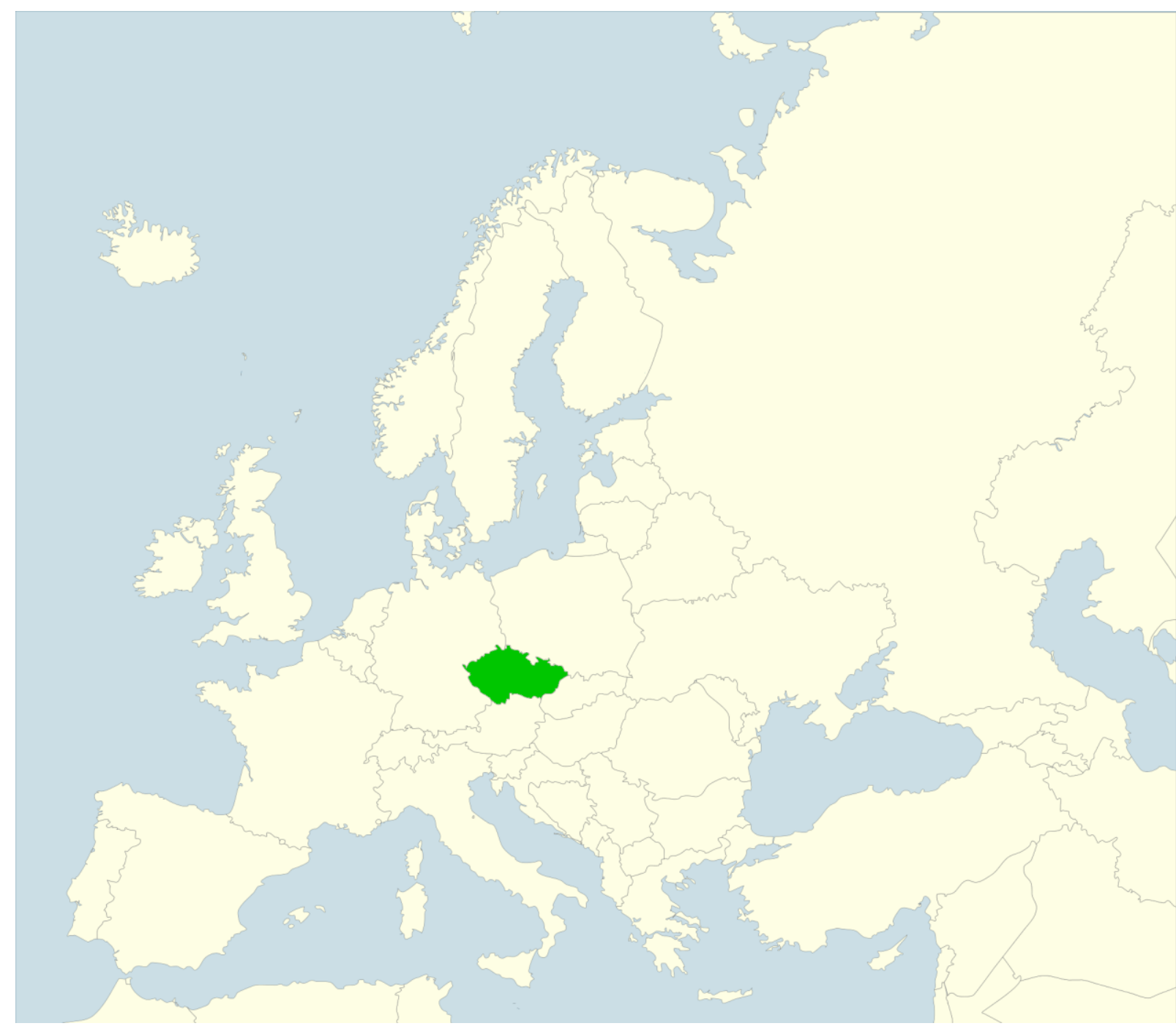

\footnotetext{
${ }^{1}$ RNDr. PhDr. Markéta Šantrůčková, PhD., Mgr. Katarína Demková, PhD., Ing. Martin Weber, Ing. Jiří Dostálek, CSc., Silva Tarouca Research Institute for Landscape and Ornamental Gardening, Květnové náměstí 391,25243 Průhonice, Czech Republic, e-mails: santruckova@vukoz.cz, demkova@vukoz.cz, weber@vukoz.cz, dostalek@vukoz.cz

2 Doc. RNDr. Zdeněk Lipský, CSc., Faculty of Science, Charles University in Prague, Albertov 6, 12800 Praha 2 , Czech Republic, e-mail: lipsky@natur.cuni.cz
} 


\begin{abstract}
The landscape of the Czech Republic currently faces droughts that are caused by several factors. One of the reasons for drought is landscape development and land cover changes. Changes in water and wetland areas and streams were studied by comparing old military maps and the present state. Water and wetland areas in fertile lowlands significantly decreased over time; the landscape was continuously dried out with the aim of increasing agricultural and woody production. While water and wetland areas occupied nearly one-third of the study area (Nové Dvory and Žehušice micro-regions in Central Bohemia) at the end of the $18^{\text {th }}$ century, the present share of these areas is only $3.5 \%$. There was a decrease of approximately $10 \%$ in each period, and nearly all of these areas disappeared by the end of the $19^{\text {th }}$ century. Water and wetland areas were changed primarily to arable land. The length of streams decreased by the end of the $19^{\text {th }}$ century. Drainage and irrigation channels were built during the $20^{\text {th }}$ century, and although they are only periodic or episodic streams, these channels increased the total length of streams.
\end{abstract}

Key words: streams, still waters, wetlands, land use changes, drought, central Europe

Abstrakt: Krajina České republiky v současnosti čelí nebezpečí sucha, které je způsobeno mnoha faktory. Mezi ně patří změny krajiny a krajinného pokryvu. $V$ článku jsou sledovány změny vodních a mokřadních ploch a délky vodních toků na podkladě starých vojenských mapování a současného stavu. Vodní a mokřadní plochy v nižinách zásadně ubyly a krajina byla vysušována s cílem zvýšit zemědělskou a lesnickou produkci. Zatímco na konci 18 . století vodní a mokřadní plochy zaujímaly skoro třetinu sledovaného území Novodvorska a Žehušicka ve středních Čechách, v současnosti je to jen 3,5\%. V každé ze sledovaných period ubylo přibližně $10 \%$ jejich rozlohy, významný úbytek těchto ploch v krajině tak nastal již v 19. století. Vodní a mokřadní plochy byly změněny převážně na ornou půdu. Délka vodních toků poklesla zejména $v$ průběhu 19. století. Současná data ukazují nárůst jejich délky, který je ale způsoben budováním zavodňovacích a odvodňovacích kanálů, jejichž délka je také započítána do celkové délky vodních toků, byt' nejsou celoročně protékány vodou.

Klíčová slova: vodní toky, vodní plochy, mokřadní plochy, změny využití krajiny, sucho, střední Evropa

\title{
1. Introduction
}

Urbanization and intensive farming resulted in landscape changes during the last two centuries almost in the entire world. These changes are related to losses of ecological and water absorption capacities as well as damage to the historical value and scenic beauty of cultural landscapes (Bastian et al., 2006). Two main trends were recognized: intensification and extensification (Antrop, 2005; Van Eetevelde and Antrop, 2009). Both of these processes influence present land cover and landscape structure and are a result of the development of society and economy (Van Eetevelde and Antrop, 2009). Agriculture is one of the most influential driving forces in countryside landscapes. The development and drivers of European agriculture over the last two centuries from the era of peasantry, through innovation, intensification, industrialization, collectivization, and commercialization to environmental awareness were described in detail by Jepsen et al. (2015).

The state of agriculture influences not only land cover but also ecological stability and water management in a landscape because agriculture is a serious water consumer and influences both water quantity and quality (Šantrůčková et al., 2015; Kniezková, 2013). Lastly, modern intensive agriculture can use land with high level of underground water where used to be wetlands, lakes or ponds. Intensification of agriculture has usually resulted in the drying out of 
water areas and wetlands and the shortening of streams (Endfield and O'Hara, 1999; Julian et al., 2015). In the Czech Republic, there used to be many ponds until the end of the $18^{\text {th }}$ century, but many of them were dried out during the $19^{\text {th }}$ century and changed to arable land, especially in the fertile lowlands of Bohemia and Moravia (Pavelková et al., 2014).

Different data sources can be used for studying land use / land cover changes. One way to study these changes is to use historical and actual statistical data about land use. These data for the Czech Republic are available for cadastral municipalities from 1845 to the present day (Bičík et al., 2010; Št'astná et al., 2015). The use of statistical data has two main disadvantages. First, the data cannot be localized within a landscape, and only the predefined land use categories of each cadastral municipality are known. Secondly, information about land use categories and their quality may not be made more precise, land use categories could be only grouped together (Šantrǔčková and Bendíková, 2014). Another approach is to gain information about land cover from old maps and aerial photographs. Old maps dating from the second half of the $18^{\text {th }}$ century are available in an appropriate resolution and topographical quality for large areas in Europe (Van Eetevelde and Antrop, 2009; Skaloš et al., 2012b; Fuchs et al. 2015; Skaloš et al., 2011). Mining information from old maps is time consuming, but maps provide precise localization of land cover patches. On the other hand, maps do not contain information about the quality of identified patches. The knowledge about landscape in the past could be deepened by studying additional sources, mainly written texts, e.g., historic encyclopedias or historical landscape surveys (Vellend et al., 2013; Endfield and O'Hara, 1999; Foster, 1992; Šantrůčková et al., 2015; Fuchs et al. 2015).

The aim of this study was to investigate the extent of changes in the areas of still waters and wetlands and the length of streams in the intensively farmed landscape (case study from the Central Bohemia) in relation to long-term land-use changes from the second half of the $18^{\text {th }}$ century to the present day. The study contributes the understanding of the deep landscape changes, mainly focus on the water and wetland areas that European landscape has experienced in the last 250 years. These changes caused that intensively farmed landscapes suffer by drought nowadays. The knowledge about the water and wetlands areas development could be a part of the drought solution. The information about landscape history is essential for future landscape planning and water management (Šantrǔčková et al., 2013).

\section{Materials and methods}

\subsection{Study area}

The study area was located in Central Bohemia, east of Kutná Hora (Fig. 1), Czech Republic. The area consists of 21 cadastral municipalities, with a total area of $113 \mathrm{~km}^{2}$. It is situated in the lowlands near the Elbe River that creates its northern border. With the exception of the foothills of the Železné Hory Mountains, the area is predominantly flat at an elevation of 200-230 m with only slight differences in elevation. The most important streams are two Elbe tributaries: Doubravka and Klejnárka. The area is located in an intensively utilized agricultural landscape, which has been used for farming since Neolithic times. The landscape is currently formed by large-scale arable fields with small patches of woodland and rural settlements. However, a number of historical landscape structures from the $15^{\text {th }}-19^{\text {th }}$ centuries (e.g., relics of the former landscape design) are among the characteristic landscape features, increasing its cultural, aesthetic and natural values (Skaloš et al., 2011). We focused on this area because it is an intensively farmed landscape with its typical problems; on the other hand, remnants of historical landscape structures are still present. 


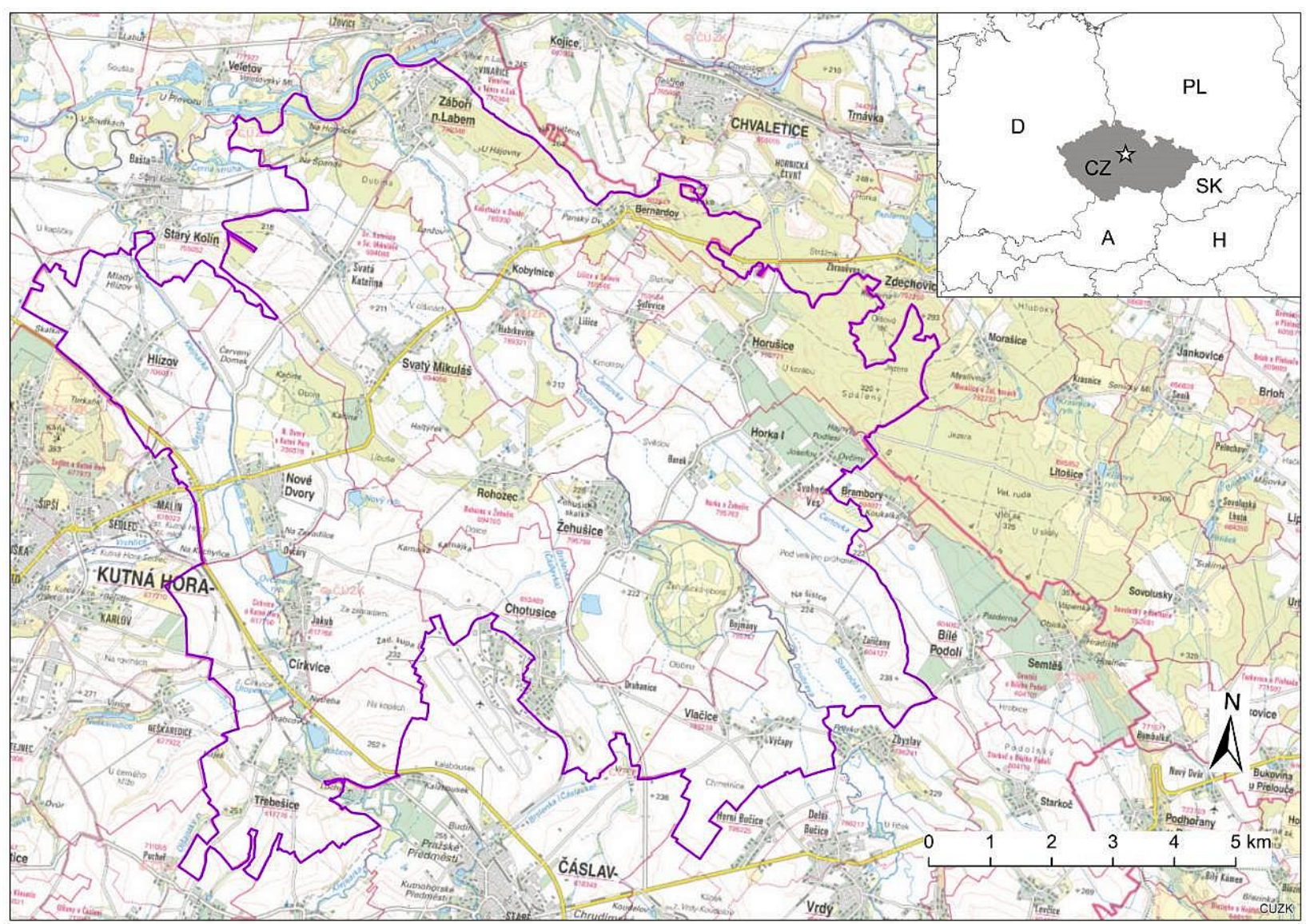

Fig 1. The study area. Source: State Administration of Land Surveying and Cadaster

\subsection{Source data}

\section{Old maps and archival sources}

Old military maps were used as a basis for further interpretation of changes in water areas and streams in different time periods. Three sets of military maps were made for the territory of the present Czech Republic - First Military Maps (1763-1783), Second Military Maps (18421852), and Third Military Maps (1874-1880). These maps are medium-scaled; the scale of the First and the Second Military Maps is 1:28,800, and the scale of the Third Military Maps is $1: 25,000$. While the First Military Maps were made without any accurate surveying or cartographic methods, the Second and Third Military Maps are much more precise and are based on a triangulation network (Petrovszki and Mészáros, 2010; Skaloš et al., 2011; Skaloš et al., 2012a).

Written archival sources were studied for the delimitation and specification of wetlands. The First Military Survey was composed of map sheets and written reports. These reports (one book for each region) describe in detail the terrain, landscape character, ponds, streams, wetlands and roads. The reports are accessible in the National Archive in Prague. The reports were made for military officers with regard to accessibility for troops and clear arrangement of terrain (Vávrová and Santrůčková, 2009).

The Second Military Survey was made in close association with stable cadastral mapping; the topography of the military maps was derived from cadastral maps, which are much more precise because they are large-scale maps (1:2,880). For precise boundaries of wetlands on the Second Military Maps, maps of stable cadaster and written cadastral reports were used. In uncertain cases, written sheets were studied. These sheets are also deposited in the National Archive in Prague.

The most difficult task was to find necessary additional information to ensure precision of the Third Military Maps because we could not use any reports made for broader area as was 
possible for the First and Second Military Maps. Information about wetlands and water areas were collected from several partial reports stored in the State Regional Archive in Prague. The two collections used were the Estate Nové Dvory for the western part of the study area (source: the description of the Estate Nové Dvory from 1864) and the Estate Žehušice for the eastern part (source: the report of evaluation of the Estate Žehušice from 1879).

\section{Present data}

Data about the present-day state of still waters and streams was taken from the Basic Water Management Map of the Czech Republic (T. G. Masaryk Water Research Institute) on the scale of 1:50,000. They are online available from the digital water management database (DIBAVOD) (for data see http://www.dibavod.cz/index.php?id=27).

Natural habitat mapping data from the Agency for Nature Conservation and Landscape Protection (@ AOPK) was used to assess proportions of wetlands (alluvial forests and alder and willow carrs, and wet meadow). The data consisted of a digitized vector output for the Czech Republic on a scale of $1: 10,000$. It was developed during the establishment of Natura 2000 (according to the Habitats Directive).

\subsection{Data processing}

Old military maps were scanned and georeferenced to spatial co-ordinate system (S-JTSK) to obtain raster maps as data sources for digitization of historical changes in water areas and wetlands (for details of georeferencing and vectorization, see Skaloš et al., 2011).

Archival sources were used to re-classify the old maps to be comparable to current maps of water areas and wetlands. Common historiographical methods (textual analysis, inner and outer critics) were applied to analyze the written sources (Black and Macraild, 2007) from which information about the quality of the selected habitats was obtained for each patch.

Water areas were separately digitized as polygons and streams as polylines. With the help of ArcGIS 10 software, the length of streams and area of still waters and wetlands were calculated.

Then, historical layers of still waters and wetlands (except from the First Military Maps) were intersected with historical and present land use published by Skaloš et al. (2011) to obtain spatio-temporal changes in still waters and wetlands (Table 1). Changes in still waters and wetlands from the First Military Maps were not quantified because of its topographic inaccuracy.

For ease of map analysis, the maps are presented as single-year and not according to mapping periods (i.e., First Military Map of 1780, Second Military Map of 1840, Third Military Map of 1880, and present map of 2010). 
Tab 1. Land cover classification categories.

\begin{tabular}{|c|c|}
\hline Land use categories & Commentary \\
\hline Built-up areas & $\begin{array}{l}\text { Continuous as well as non-continuous built-up areas (isolated } \\
\text { built-up areas outside town residential area). It includes } \\
\text { residential built-up areas as well as various technical structures, } \\
\text { yards, warehouses, car parks etc. As well as buildings it also } \\
\text { includes other built-up surfaces excluding land transport } \\
\text { system. }\end{array}$ \\
\hline Arable land & $\begin{array}{l}\text { Agricultural land utilized as arable land. It includes both, large, } \\
\text { intensively utilized agricultural fields and small croft-type fields. }\end{array}$ \\
\hline Pastures & $\begin{array}{l}\text { The category includes permanent grassland utilized as pastures } \\
\text { for grazing livestock. }\end{array}$ \\
\hline Orchards & $\begin{array}{l}\text { Extensively or intensively utilized green surfaces with fruit wood } \\
\text { species are concerned. }\end{array}$ \\
\hline Forests & $\begin{array}{l}\text { Growths composed of various kinds of wood species (trees and } \\
\text { bushes) and having functions as forest. }\end{array}$ \\
\hline Non-forest vegetation & $\begin{array}{l}\text { Growths composed of various kinds of wood species (trees and } \\
\text { bushes), connected green or scattered green in open } \\
\text { landscape. }\end{array}$ \\
\hline Parks and gardens & $\begin{array}{l}\text { The category includes surfaces of parks, gardens, graveyards } \\
\text { and playgrounds. The parks are understood as larger surfaces } \\
\text { inside or on the outskirts of built-up parts of settlement. Wood } \\
\text { vegetation within town residential area was not included into } \\
\text { this category with the exception of spacious garden surfaces } \\
\text { having connection with open landscape. }\end{array}$ \\
\hline Roads & $\begin{array}{l}\text { All types of land transport network. Paved roads of all classes } \\
\text { as well as unpaved roads, so called country roads, railways and } \\
\text { various kinds of specific transport networks are concerned. }\end{array}$ \\
\hline Still waters & $\begin{array}{l}\text { Water surfaces were included regardless of their way of origin, } \\
\text { vegetation abundance or a measure of their bottoms and banks } \\
\text { reinforcement. }\end{array}$ \\
\hline Water streams & The category includes all types of flowing waters. \\
\hline $\begin{array}{l}\text { Alluvial forests and alder } \\
\text { and willow carrs }\end{array}$ & $\begin{array}{l}\text { Alluvial forest is a hardwood forest found in river floodplains on } \\
\text { low levees, ridges and terraces that are slightly elevated above } \\
\text { floodplain swamp and are regularly flooded for a portion of the } \\
\text { growing season. } \\
\text { Alder and willow carrs is a type of waterlogged wooded terrain } \\
\text { dominated by Alnus sp. or Salix sp. }\end{array}$ \\
\hline Wet meadows & $\begin{array}{l}\text { A wet meadow is a field habitat vegetated by grass and other } \\
\text { non-woody plants (grassland) with soils that are water-saturated } \\
\text { for part or all of the growing season. }\end{array}$ \\
\hline
\end{tabular}

\section{Results}

We analyzed the intersection of land cover maps and employed a correlation matrix for the quantification of land cover changes with focus on the water and wetland areas. The extent of water areas and wetlands changed rapidly in the study area over the last 250 years (Fig. 2). Generally, the areas decreased at a great rate until the end of $19^{\text {th }}$ century in all categories. However, the temporal change of each category in the last period is different. While still waters, and alluvial forests and alder and willow carrs gradually decreased with a slight increase in the last period, wet meadows disappeared almost completely. Wet meadows, areas with 
the highest proportion in the study area at the beginning of survey $(20 \%)$, also decreased at a gradual rate, but the greatest losses occurred between last two time periods (Table 2).
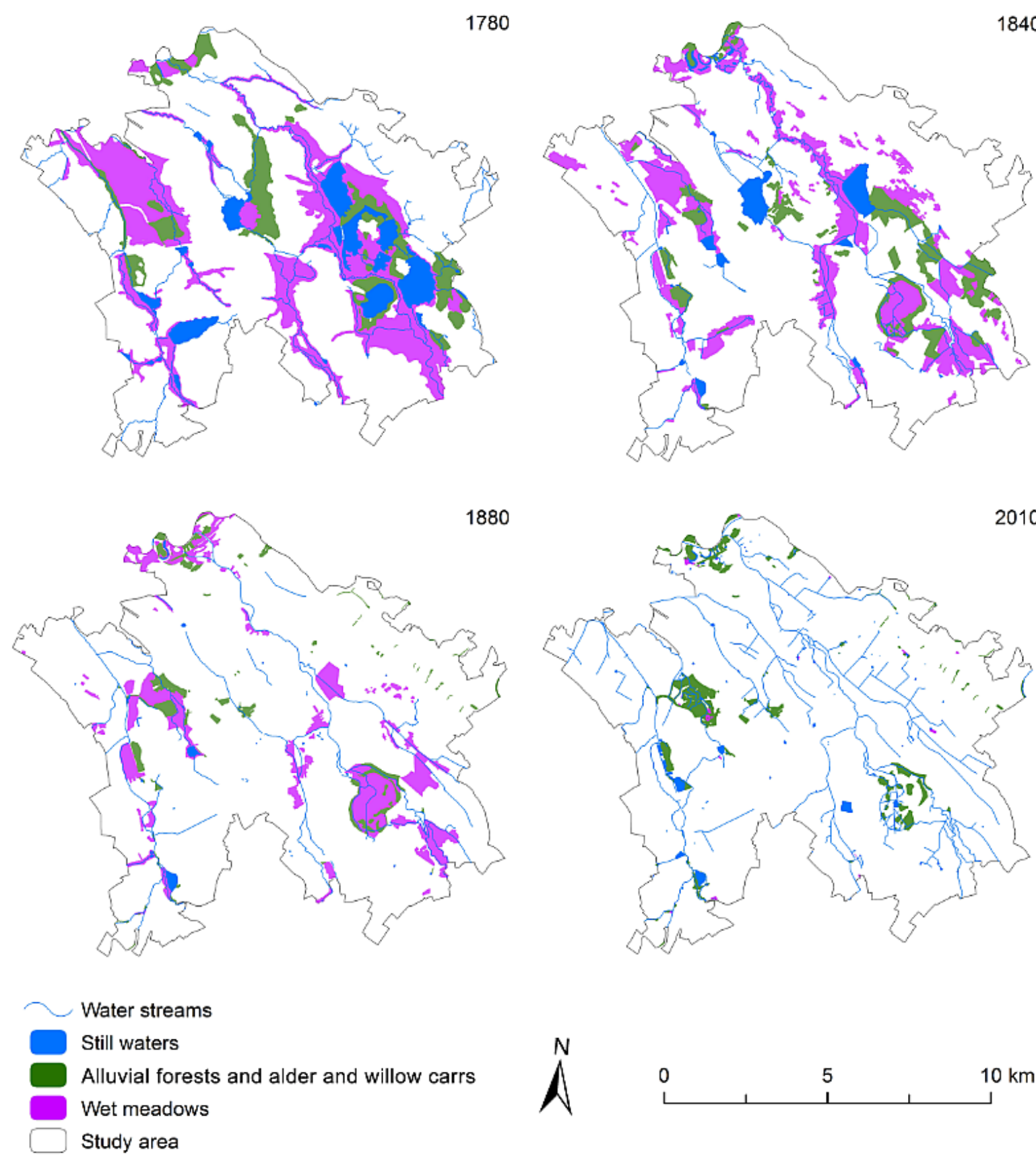

Fig 2. Water stream, still water and wetland distribution over the observed period.

Tab 2. Dynamics of still water and wetland areas over the observed time period.

\begin{tabular}{|l|c|c|c|c|c|c|c|c|}
\hline & \multicolumn{4}{|c|}{ Area (ha) } & \multicolumn{3}{c|}{ Proportion of the study area (\%) } \\
\hline Year of observation & 1780 & 1840 & 1880 & 2010 & 1780 & 1840 & 1880 & 2010 \\
\hline $\begin{array}{l}\text { Alluvial forests and } \\
\text { alder and willow carrs }\end{array}$ & 836.3 & 651.9 & 253.2 & 314.7 & 7.4 & 5.8 & 2.2 & 2.8 \\
\hline Wet meadows & 2136.9 & 1539.9 & 867.6 & 10.8 & 18.9 & 13.6 & 7.7 & 0.1 \\
\hline Still waters & 615.2 & 247.0 & 29.6 & 52.0 & 5.4 & 2.2 & 0.3 & 0.5 \\
\hline
\end{tabular}


The length of streams decreased from 123 to $94 \mathrm{~km}$ until the end of $19^{\text {th }}$ century due to straightening of natural watercourses. Consequently, it has increased by $76 \%$ to $165 \mathrm{~km}$ in present day (Table 3).

Tab 3. Water stream length dynamics over the observed time period.

\begin{tabular}{|l|c|c|c|c|}
\hline & \multicolumn{4}{|c|}{ Length $(\mathrm{km})$} \\
\hline Year of observation & 1780 & 1840 & 1880 & 2010 \\
\hline Water streams & 123.4 & 117.6 & 94.0 & 165.4 \\
\hline
\end{tabular}

Still waters almost disappeared during the period $1840-1880$. Only $14 \%$ of their area was preserved. They were converted mostly into arable land (72\%). Approximately $10 \%$ were transformed into non-forest vegetation (Table 4).

In next period (1880-2010), nearly $43 \%$ of the water area was preserved. Conversely, $27.5 \%$ of the area was converted to arable land, and $22 \%$ to forest land and non-forest vegetation (approximately $13 \%$ and $9 \%$, respectively).

Tab 4. Conversion of still waters and wetland habitats into other land use categories in the $2^{\text {nd }}(1840-1880)$ and $3^{\text {rd }}$ (1880-2010) period of analysis (expressed in \% from the total area of the habitat).

\begin{tabular}{|c|c|c|c|c|c|c|}
\hline \multirow{2}{*}{ Land use categories } & \multicolumn{2}{|c|}{ Still waters (\%) } & \multicolumn{2}{|c|}{$\begin{array}{l}\text { Alluvial forests and alder } \\
\text { and willow carrs (\%) }\end{array}$} & \multicolumn{2}{|c|}{ Wet meadows (\%) } \\
\hline & $2^{\text {nd }}$ & $3^{\text {rd }}$ & $2^{\text {nd }}$ & $3^{\text {rd }}$ & $2^{\text {nd }}$ & $3^{\text {rd }}$ \\
\hline Built-up areas & 0.99 & 1.26 & 0.27 & 0.03 & 0.35 & 0.74 \\
\hline Arable land & 71.71 & 27.51 & 50.12 & 2.67 & 50.52 & 69.65 \\
\hline Pastures & 0.10 & 0.23 & 0.00 & 0.00 & 0.00 & 0.24 \\
\hline Orchards & 0.00 & 0.01 & 0.00 & 0.02 & 0.00 & 0.16 \\
\hline Forests & 2.36 & 13.28 & 10.63 & 11.10 & 0.62 & 6.45 \\
\hline Non-forest vegetation & 9.92 & 9.37 & 4.49 & 1.78 & 6.7 & 6.62 \\
\hline Parks and gardens & 0.43 & 2.78 & 0.23 & 0.02 & 0.36 & 0.74 \\
\hline Still waters & 14.16 & 43.09 & 1.50 & 0.02 & 3.25 & 0.94 \\
\hline Water streams & 0.00 & 1.55 & 0.00 & 0.15 & 0.00 & 0.77 \\
\hline Roads & 0.19 & 0.50 & 0.04 & 0.00 & 0.30 & 0.79 \\
\hline $\begin{array}{l}\text { Alluvial forests and alder and } \\
\text { willow carrs }\end{array}$ & 0.00 & 0.00 & 21.54 & 84.20 & 1.54 & 11.16 \\
\hline \multirow[t]{2}{*}{ Wet meadows } & 0.14 & 0.43 & 11.19 & 0.00 & 36.98 & 1.74 \\
\hline & 100 & 100 & 100 & 100 & 100 & 100 \\
\hline
\end{tabular}

Both alluvial forests and alder and willow carrs, and wet meadows were converted into arable land by 50\% (each) between 1840 and 1880 (Table 4). Moreover, approximately $11 \%$ of alluvial forests and alder and willow carrs were replaced by wet meadows, and almost $11 \%$ were classified as forest land. Approximately $6 \%$ of wet meadows were classified as non-forest vegetation. However, only $22 \%$ of alluvial forests and alder and willow carrs, and more than one third of wet meadow areas were preserved until the end of $19^{\text {th }}$ century.

During the next period (1880-2010), 84\% of alluvial forests and alder and willow carrs were preserved and $11 \%$ were converted to forest land. On the other hand, wet meadows had nearly disappeared, as mentioned previously. Only $2 \%$ were preserved in the last period. Even $70 \%$ of 
them were transformed into arable land. Furthermore, $11 \%$ were converted to alluvial forests and alder and willow carrs, and 6.5\% to forest land (Table 4).

\section{Discussion}

\section{Water and wetland dynamics}

The investigation of changes in the area of still waters and wetlands in the intensive agricultural landscape during the last two centuries proved the hypothesis that these areas seriously decreased and are marginalized in the present landscape. While water and wetland areas occupied nearly one-third of the study area at the end of the $18^{\text {th }}$ century, the present share of these areas is only $3.5 \%$. There was a decrease of approximately $10 \%$ in each period, and nearly all of these areas disappeared by the end of the $19^{\text {th }}$ century. This development corresponds with the situation in the Czech Republic as whole (Pavelková et al., 2014; Bičík et al. 2010) as well as in the other European countries (Van Eetevelde and Antrop, 2009; Mallinis et al., 2011).

On the other hand, the length of the streams decreased during the $19^{\text {th }}$ century with minimum on the maps of the Third Military Mapping, but it increased in the $20^{\text {th }}$ century. The present length of the streams was higher than was measured on the maps of the First Military Mapping. Alternatively, Lipský and Kukla (2009) and Lipský et al. (2011a) focused on three main water courses in the same area (Doubrava, Klejnárka, Brslenka) and concluded that their length decreased during the $19^{\text {th }}$ century and remained nearly unchanged in the $20^{\text {th }}$ century. The length of regular streams decreased by nearly 25\% (Lipský et al., 2012). Our investigation is biased by artificially constructed water channels that were created mainly in the second half of the $20^{\text {th }}$ century for irrigation or drainage of the fields. These channels are registered on the water management map as streams, although more than one-third of them are only periodic or episodic (Lipský et al., 2012).

The results confirm that intensification of agriculture seriously influenced all components of the water regime in the area. Development in riverine landscapes with accompanying liquidation of water areas, wetlands, forests and grasslands, and their replacement by arable land is very negative in terms of flood protection, water retention and its accumulation in the landscape and also environmental stability (Lipský et al., 2011b). This intensification began in fertile lowlands at the end of the $18^{\text {th }}$ century in connection with the abolition of serfdom and vassalage, an increase in population size and industrialization. New technologies and crops, e.g., sugar beet, enabled the cultivation of wetlands; therefore, most wetland and water areas were changed to arable land by the end of the $19^{\text {th }}$ century. Streams were remodeled to drain the area, and their total lengths were shortened (Skaloš et al., 2012b; Jepsen et al., 2015; Šantrůčková et al., 2015; Štengl, 1992; Froněk, 2009).

Intensification and industrialization of agriculture continued throughout the $20^{\text {th }}$ century, especially in the second half through socialist collectivization. Large collective open fields were created, heavy machinery was used, and small landscape elements (e.g., wet meadows around springs, solitary trees or small tree groups) were destroyed (Grešlová Kušková, 2013; Jepsen et al., 2015). On the other hand, fields less accessible to mechanization were abandoned and reforested (Janáč et al., 2010). Additionally, some former water areas and alluvial forests were changed to intensively managed forest plantations. Intensification of the agriculture and forest production was connected to drainage of the landscape; one-fifth of the model area was drained. Streams were remodeled and straightened, and drainage channels were built. On the other hand, the landscape began to suffer from drought and wind erosion, and fields had to be irrigated (Lipský et al., 2012; Skaloš et al., 2012b). The knowledge of water and wetland dynamics in the past is essential for responsible and successful landscape planning (Santrůčková et al., 2013; Lipský et al., 2013). The responsible management is an important contribution to solution present-day problems (drought and floods). 


\section{Use of old maps and current source data}

Old military maps are very useful for multi-temporal landscape analyses. They represent a unique primary historical source of information about the character of lost landscape structures. Thanks to the timeline of military maps and their medium-scale sizes, the maps recorded trends in cultural landscape development during a period of 250 years and over a large area (more than $100 \mathrm{~km}^{2}$ ) (Skaloš et al., 2011). Moreover, when combined with written archival sources and stable cadaster maps and reports, it was possible to identify wetlands and their quality as well. However, the delineation of boundaries between landscape patches is often a subjective matter (Brůna and Křováková, 2006) as a result of the rather unclear borders between individual landscape elements, especially in the First Military Maps.

The low geodetic accuracy of the First Military Maps was caused by the absence of a consistent triangulation system (Paldus, 1919). Therefore, there were inaccuracies in the interpretation of the location of landscape elements, which caused shifts in their position. Hence, we did not illustrate changes of waters and wetland habitats from 1780 by overlaying the land use data from 1840 as also Skaloš et al. (2012a). We presented only data about the area coverage and loss from the period of the First Military Mapping.

Compared to the First Military Maps, the Second and Third Military Maps were based on triangulation; therefore, the planimetric data of both maps was more reliable (Skaloš et al., 2011). Although old maps have some disadvantages, they became very good sources of historical information in various scientific branches (e.g. geography, landscape ecology, landscape planning, botany) (Sádlo and Karlík, 2002; Petrzovski and Mészáros, 2010; Skaloš et al., 2011; Skaloš et al., 2012a).

On the other hand, current source data are compared to the military maps and thus, more precise and detailed. Final layers of streams, still waters and wetlands on the base of old maps were more generalized, while natural habitat mapping data were very accurate because of large scale of mapping. Interpretation of such different source maps requires special attention when studying changes in landscape dynamics; therefore, the results of our study should not be considered as absolute values. Nevertheless, analysis of long-term changes of waters and wetlands on the basis of old military maps can contribute to a better understanding the dynamics and processes that have formed present landscape structure and states of waters and wetlands over the past 250 years (Šantrůčková et al., 2015).

\section{Conclusion}

The main story of the typical lowland landscape describes the drainage and decrease in water and wetlands areas caused by the increase in agricultural land area and the intensification of agriculture practices (Bastian et al., 2006; Julian et al., 2015; Pavelková et al. 2014). Water and wetland areas in the fertile lowlands in the Czech Republic decreased dramatically over the last 250 years. The landscape was continuously dried out with the aim of increasing agricultural and woody production; therefore, the current landscape is more at risk of drought than it was at the end of the $18^{\text {th }}$ century. Whereas water surfaces, and alluvial forests and alder and willow carrs reached their minimum sizes at the end of the $19^{\text {th }}$ century, and then their area was stable or slightly increased, wet meadows decreased continuously throughout the entire researched period. Water and wetland areas were changed primary to arable land. During the $20^{\text {th }}$ century, still waters, and alluvial forests and alder and willow carrs were also converted to forest lands (i.e., forest plantations), while wet meadows were changed to alluvial forests and alder and willow carrs.

The length of streams decreased by the end of the $19^{\text {th }}$ century. Many drainage and irrigation channels were built during the $20^{\text {th }}$ century, and although they were only periodic or episodic streams, the channels increased the total length of streams during this time.

The paper summarizes the water and wetland dynamics in the fertile lowlands on the case study of Novodvorsko and Žehušicko (Central Bohemia). The results are important for responsible water management and landscape planning to prevent the risk of drought. 


\section{Acknowledgements}

This research was funded by institutional support from the Silva Tarouca Research Institute for Landscape and Ornamental Gardening (VUKOZ-IP-00027073) and by a long-term research project of the Faculty of Science, Charles University (PRVOUK P43 Geografie).

References

[1] Bastian, O., Krönert, R. \& Lipský, Z. (2006). Landscape diagnosis on different space and time scales - a challenge for landscape planning. Landscape Ecology 21, 359-374. DOI: $10.1007 / \mathrm{s} 10980-005-5224-1$.

[2] Bičík, I., Jeleček, L., Kabrda, J. et al. (2010). Vývoj využití ploch v Česku. Praha: Česká geografická společnost.

[3] Black, J. \& Macraild, D. M. (2007). Studying History. Basingstoke: Palgrave Macmillan.

[4] Brůna, V. \& Křováková, K. (2006). Exploitation of old maps of medium and large scale for investigation of forest development (pp. 111-117). In Neuhöferová, P., ed., Forests history and development in the Czech countries. Praha: Department of Silviculture FLE ČZU.

[5] Endfield, G. H. \& O’Hara, S. L. (1999). Degradation, Drought, and Dissent: An Environmental History of Colonial Michoacán, West Central Mexico. Annals of the Association of American Geographers 89(3), 402-419.

[6] Foster, D. R. (1992). Land-use history (1730-1990) and vegetation dynamics in central New England, USA. Journal of Ecology 80, 753-772. DOI: 10.2307/2260864.

[7] Froněk, D. (2009). Vývoj struktury a počtu pěstitelů řepy na území dnešní ČR. Listy cukrovarnické a řepařské 125(12), 351-355.

[8] Fuchs, R., Verburg, P. H., Clevers, J. G. P. W. \& Herold, M. (2015). The potential of old maps and encyclopedias for reconstructing historic European land cover/use change. Applied Geography 59, 43-55. DOI: 10.1016/j.apgeog.2015.02.013.

[9] Grešlová Kušková, P. (2013). A case study of the Czech agriculture since 1918 in a sociometabolic perspective - From land reform through nationalism to privatization. Land Use Policy 30, 592-603. DOI: 10.1016/j.landusepol.2012.05.009.

[10] Janáč, J., Jeleček, L. \& Chromý, P. (2010). LUCC in East Central and Southeast Europe post-communist countries from 1960 s to the end of the $20^{\text {th }}$ century and its historicgeographical roots. Acta Universitatis Carolinae Geographica 45(2), 19-30.

[11] Jepsen, M. R., Kümmerle, T., Müller, D. et al. (2015). Transitions in European landmanagement regimes between 1800 and 2000. Land Use Policy 49, 53-64. DOI: 10.1016/j.landusepol.2015.07.003.

[12] Julian, J. P., Wilgruber, N. A., de Beurs, K. M., Mayer, P. M. \& Jawarneh, R. N. (2015). Long-term impacts of land cover changes on stream channel loss. Science of the Total Environment 537, 399-410. DOI: 10.1016/j.scitotenv.2015.07.147.

[13] Kniezková, T. (2013). Interest of Czech population in water management. European Countryside 5(3), 197-211. DOI: 10.2478/euco-2013-0013.

[14] Lipský, Z., Šantrůčková, M., Weber, M. et al. (2011a). Vývoj krajiny Novodvorska a Žehušicka ve středních Čechách. Praha: Karolinum.

[15] Lipský, Z., Demková, K., Skaloš, J. \& Kukla, P. (2011b). The influence of natural conditions on changes in landscape use: a case study of the Lower Podoubraví region (Czech Republic). Ekológia (Bratislava) 30(2), 239-256. DOI: 10.4149/ekol_2011_02_239.

[16] Lipský, Z., Weber, M., Stroblová, L. et al. (2012). Současnost a vize Novodvorska a Žehušicka ve středních Čechách. Praha: Karolinum. 
[17] Lipský, Z. \& Kukla, P. (2009). Historické změny vodní složky krajiny v dolním Podoubraví (pp. 147-153). In Dreslerová, J., ed., Venkovská krajina 2009, Brno: CZ-IALE and Veronica.

[18] Mallinis, G., Emmanoloudis, D., Giannakopoulos, V. \& Maris, F. (2011). Mapping and interpreting historical land cover/land use changes in a Natura 2000 site using earth observation data: The case of Nestos delta, Grrece. Applied Geography 31, 312-320. DOI: 10.1016/j.apgeog.2010.07.002.

[19] Paldus, J. (1919). Die Militärischen Aufnahmen im Bereiche der Habsburgischen Länder aus der Zeit Kaiser Josephs II. Wien: Hölder.

[20] Pavelková, R., Frajer, J. \& Netopil, P. (2014). Historické rybníky České republiky. Srovnání současnosti se stavem v 2. polovině 19. století. Praha: Výzkumný ústav vodohospodářský T. G. Masaryka, v.v.i.

[21] Petrovszki, J. \& Mészáros, J. (2010). The Great Hunagarian plain in the sheets of the Habsburg military surveys and some historical maps - a case study of the Körös/Criș drainage basin. Acta Geodaetica et Geophysica Hungarica 45(1), 56-63. DOI: 10.1556/AGeod.45.2010.1.9.

[22] Sádlo, J. \& Karlík, P. (2002). Landscape-ecological interpretation of old maps through geobotany: an example of Joseph's survey (pp. 58-62). In Němec, J., ed., Krajina 2002: Od poznání k integraci, Praha: MŽP.

[23] Skaloš, J., Engstová, B., Trpáková, I., Šantrůčková, M. \& Podrázský, V. (2012a). Long-term changes in forest cover 1780-2007 in central Bohemia, Czech Republic. European Journal of Forest Research 131(3), 871-884. DOI: 10.1007/s10342-011-0560-y.

[24] Skaloš, J., Molnárová, K. \& Kottová, P. (2012b). Land reforms reflected in the farming landscape in East Bohemia and in Southern Sweden - Two faces of modernisation. Applied Geography 32, 114-123. DOI: 10.1016/j.apgeog.2012.06.003.

[25] Skaloš, J., Weber, M., Lipský, Z., Trpáková, I., Šantrůčková, M., Uhlírová, L. \& Kukla, P. (2011). Using old military survey maps and ortophotograph maps to analyse long-term land cover changes - Case study (Czech Republic). Applied Geography 31, 426-438. DOI: 10.1016/j.apgeog.2010.10.043.

[26] Šantrůčková, M. \& Bendíková, L. (2014). Assessment of land use changes in landscape conservation areas based on LUCC database (pp. 83-98). In Bičík, I., Himiyama, Y., Feranec, J. \& Kupková, L., eds., Land Use/Cover Changes in Selected Regions in the World. Volume IX. Prague: IGU-LUCC.

[27] Šantrůčková, M., Dostálek, J. \& Demková, K. (2015). Assessing long-term spatial changes of natural habitats using old maps and archival sources: a case study from Central Europe. Biodiversity and Conservation 24, 1899-1916. DOI: 10.1007/s10531-015-0912-x.

[28] Šantrůčková, M., Weber, M., Lipský, Z. \& Stroblová, L. (2013). Participative landscape planning in rural areas: A case study from Novodvorsko, Žehušicko, Czech Republic. Futures 51, 3-18. DOI: 10.1016/j.futures.2013.04.005.

[29] Št’astná, M., Vaishar, A., Vavrouchová, V., Ševelová, M., Kozlovská, S., Doskočilová, V. \& Lincová, H. (2015). Changes of a rural landscape in Czech areas of different types. European Countryside 7(2), 111-133. DOI: 10.1515/euco-2015-0008.

[30] Štengl, R. (1992). Die Zuckerindustrie in Böhmen und Mähren. Zuckerindustrie 117(6), 435-440.

[31] Van Eetevelde, V. \& Antrop, M. (2009). Indicators for assessing changing landscape character of cultural landscapes in Flanders (Belgium). Land Use Policy 26, 901-910. DOI: 10.1016/j.landusepol.2008.11.001.

[32] Vávrová, V. \& Šantrůčková, M. (2009). Krajina Novodvorska a Žehušicka v popisu k I. vojenskému mapování. Historická geografie 35(1), 213-228. 
[33] Vellend, M., Brown, C. D., Kharouba, H. M., McCune, J. L. \& Myers-Smith, I. H. (2013). Historical ecology: Using unconventional data sources to test for effects of global environmental change. American Journal of Botany 100(7), 1294-1305. DOI: $10.3732 / a j b .1200503$. 